\title{
AN EMPIRICAL STUDY ON LEAN MANAGEMENT AND HRM PRACTICES IN RELATION TOWARDS OPERATIONAL PERFORMANCE
}

\author{
Azhani Ismail \\ Faculty of Industrial Management, University Malaysia Pahang; azhani2013@gmail.com \\ Yuserrie Zainuddin \\ Faculty of Industrial Management, University Malaysia Pahang;yuserrie@ump.edu.my
}

\begin{abstract}
In recent years, the matter of lean management (LM) and human resource management (HRM) practices have been commonly used to observe operational performance (OP). One of the distinctive features of LM and HRM practices is that better performance is achieved through the people in the organization. Many researchers have demonstrated that investments in human capital can significantly influence organizational objectives and outcomes. The resource-based view (RBV) theory perspective has been extensively utilized to empirically test and predict these organizational objectives and outcomes. This study investigates from RBV theory perspective, the mediating effect of HRM practices on the relationship between LM and OP within public sector in Malaysia. The main research question addressed by this study is whether LM enhances OP directly or indirectly through the support of the HRM practices. A survey research method is adopted to collect data from Malaysia local authorities. The analysis of the research model uses Partial Least Square (PLS) based software SmartPLS 3. The results will provide practitioners with guidelines in implementing LM more efficiently and effectively for enhancing OP of their organizations.
\end{abstract}

Keywords: lean management, human resource management practices, operational performance, resource-based view public sector

\section{Introduction}

Operational performance (OP) is an important contribution which is about adopting approach to strengthen processes in an organization to stimulate growth and improvements in productivity. In recent years, there has been a growing concern in resource-based view (RBV) theory, together with the concepts of competence and capability for analyzing strategic and operational problems (Bourne, Mills and Faull, 2003) in the organization. Writers and few studies in this field suggest that such a perspective can explain how superior performance can be achieved and maintained (Marshall, 2014; Uhrin, Bruque-Cámara and Moyano-Fuentes, 2017).

In the literature, majority of studies in public sector operations management are focused on improving the public sector, regarding customer focus, quality, and process efficiency (Radnor and Osborne, 2013), which have raised the need for strategies on how the public sector can be improved (Denhardt and Denhardt, 2000). It has been found that efforts to introduce continuous improvement principles and practices in government have gained increased acceptance as government departments and agencies at the federal, state and local levels evaluate new methods to reduce waste and increase efficiency in improving OP. In this sense, lean management (LM) has been presented as capable to fulfil the needs of key stakeholders, and to stretch their resources towards producing more value for the customers (Radnor, 2012) since the foundation of LM is to instil in the employees a desire for continuous improvement (Latham, Almost, Mann and Moore, 2005).

While a growing body of literature exists, limited empirical evidence is available in this context in Malaysia public sector. It is against this backdrop that a conceptual framework is proposed for public sector in Malaysia with the aim to investigate the role of LM in improving OP with the mediating effect of human resource management (HRM) practices. This study examines LM from the perspective of the RBV of the organization. It explores the human resources as key resources that cannot be easily duplicated, and for which ready substitutes are not available. Such key resources are formed by employees' selection and hiring, training and development, performance evaluation, and 
rewards and incentive of the organization. It demonstrates the important role of HRM practices in developing resources that are imperfectly imitable and difficult to duplicate. Based on data from 149 Malaysia local authorities (LAs), the study empirically demonstrates that achieving high level of OP of organization results from LM practices which in turn, is driven by HRM practices.

This paper begins with an introduction, followed by a literature review in the area, and discusses the methodology and data analysis of the study. Finally makes some concluding remarks.

\section{Literature Review}

This study attempts to understand how LM effect OP via HRM practices in Malaysia public sector. It looks into the performance of organization in the public sectors, particularly in the LAs in Malaysia. The LAs are selected because of their features that exist, particularly in terms of resources, capabilities, positions, roles and responsibilities, services provided and the system practiced which may indirectly reflect the real state of the public sector in Malaysia (Yusoff, 2008; Talib, 2010; Zakaria, 2011). OP is defined from logistics point of view, which is the extent to which an organization is successful in achieving its planned targets by carefully and considered use of limited resources (Hookana, 2011) as well as being able to conduct its internal operations smoothly and efficiently (Zakaria, 2011). The OP is measured through an appropriate combination of two dimensions: (1) efficiency, and (2) effectiveness (Mouzas, 2006, Hookana, 2011).

Nowadays under the global economic constraints, the main strategic issues challenges the public sector are efficiency and doing more with less. Fiscal pressures, economic constraints, and the demand for greater sustainability in the delivery of services, usage of resources, and the potential environmental toxicity of products used in service delivery and at the same time contain expenditure growth will continue to force the public sector to be resource efficient and optimize functions and service delivery processes in order to be able to do more with less. Moreover, the existence of globalization and the borderless world forces public sector to deal with the clients with information, knowledgeable, intelligent and expect something more than the satisfaction or expectations set by them on the service provided. Citizens are demanding that public sector be made more accountable for what they achieve with taxpayers' money (Curristine, Lonti and Joumard, 2007).

Johnston and Jones (2004) observe that over the past three decades, criticisms about government performance have surfaced across the world from all points of political spectrum. They note that critics proclaim governments to be inefficient, ineffective, too large, too costly, overly bureaucratic, overburdened by unnecessary rules, unresponsive to public wants and needs, secretive, undemocratic, invasive into the private rights of citizens, self-serving, and failing in the provision of either the quantity or quality of services deserved by the taxpaying public (Hamid, Hamali and Abdullah, 2016). The Public Complaints Bureau (PCB) under the Prime Minister's Department also recorded that among the main reasons identified as the driving factors for the public to make complaints against the quality of service in government departments are due to delays in carrying out official duties or no action at all, the decision is deemed unfair, the failure to enforce the rules and laws, and the lack of public facilities (PCB, 2017) to meet the customer's needs. About $17 \%$ of total complaints received are attributed to LAs throughout the country (Zakaria, 2011). Beside these external criticisms, Talib (2010) pointed that among the internal problems often face by LAs are related to the acquisition of the collection, the question of financial resources to cover the costs of maintenance, staffing and human resources issues.

All of these factors become the biggest challenge to public sector's growth and should be given attention since the public sector is the only agent of change who serves as a driver for economic development to prepare Malaysia to become one of the developed countries by 2020 . The government has been emphasizing the enhancement of service delivery systems in the public sector under its Excellent Work Culture Movement since the early 1990s. Many service improvement programs have been undertaken by the government (Zakaria, Al Mamun, Nawi and Razak, 2016), such as benchmarking, key performance indicators (KPIs), balanced scorecard (BSC), focus groups, international standards organization (ISO), blue ocean strategy, total quality management (TQM), business process reengineering (BPR), strategic management, etc. The government has also committed to a Government Transformation Program (GTP) in accordance with the principles of 1Malaysia, People First, Performance Now. The rationale for the GTP is that the government needs a new way of doing things to both accelerate and sustain impact and enhance performance (Hamid, Hamali and Abdullah, 2016).

It seems that various management strategies have been implemented in public sectors especially to fasten the delivery of services to the customer and reduce administrative cost. However, the actual 
effects and impacts of these strategies have not been extensively documented (Hamid, Hamali and Abdullah, 2016). Given the importance of measuring and controlling performance and the shortcomings of existing efforts, measures to enhance the performance of public sectors, especially LAs are therefore crucial to ensure that these organizations are capable of meeting the increasing demands from the communities for a more citizen-driven and higher standard of urban services.

The need for a new performance measurement to be established for LAs has been scrutinized from many directions. Political masters, government officials, media and community leaders, all have continuously reiterated the importance of LAs improving their service through a clear long-term direction; customer focus; strong communication and feedback system; high integrity and transparency; enhanced people participation; and continuous efforts to inculcate a quality culture in their organizations (Yusoff, 2008). A number of writers and influential personalities in the field of local administration in Malaysia also have voiced their concerns about the need to revisit various aspects of LAs to improve their management and operations. Talib (2010) in his research found that LAs face problems in identifying internal factors that can improve the quality of service delivery systems. In another study, Yusoff (2008) called for extensive research and re-examination of the LAs in various areas, including new dimension of managing LAs in the current changing environment. Recently, research by Hamid, Hamali and Abdullah (2016) found that a good measurement system needs to be continually changed in public sectors in order to remain effective.

In recent years, managers in public sector have been extensively exposed to the achievements of Japanese and Western organizations that have implemented LM, which emphasized that establishing a LM organizational culture very much depends on the organization's ability to select, develop, engage, and inspire human resources through effective performance management strategies (Marshall, 2014). In this sense, human resources are the main drivers and principal value creators of the output of the knowledge industry, and also the intellectual capital or the infrastructure investment. An organization that aspires to perform well should ensure that its HRM practices are synergistic and consistent with its organizational strategy in order to spur both individual and organizational performance (Ulrich, 2013, Sagwa, K'Obonyo and Ogutu, 2015). RBV is often use as theory background that describes human capital as the value gained by developing human resources which are valuable, rare, imperfectly imitable, or without an equivalent substitute can lead to sustainable competitive advantage for the organization (Barney, 1991).

LM is about people and gaining everyone's engagement in continuous improvement. In the present research, LM is solely referred to internally-focused operation (Fok-Yew, 2016). LM is defined as "an integrated socio-technical system" (Narasimhan, Swink and Kim, 2006; Shah and Ward, 2007; Moyano-Fuentes and Sacristán-Díaz, 2012; Drotz, 2014; Fok-Yew, 2016), with a long-term philosophy, where the right processes will produce the right results and value can be added to the organization by continuously developing people and partners, while continuously solving problems to drive organizational learning (Liker, 2004; Puvanasvaran, 2011). A people centric lean culture popularized by Toyota Production System (TPS) purists serves as the lens throughout the LM implementation strategy. Similar to Dombrowski and Mielke (2013), this study draws from the "Four Principle (4P) Categories of Lean developed by Liker (2004) to guide the understanding of the key elements associated with LM which include four dimensions: (1) philosophy; (2) process; (3) people and partners, and (4) problem solving.

Following Marshall (2014), this study defines HRM practices from the LM viewpoint as a set of practices, processes, and procedures that are utilized to select, develop, appraise, and reward the organization's human resources as a means of achieving LM implementation efficiently and effectively. This study suggests that the HRM practices should be comprised of four primary dimensions: (1) selection and hiring, (2) training and development, (3) performance evaluation, and (4) rewards and incentives (Batt, 2002; Boselie, Dietz and Boon, 2005; Azmi, 2008; Marshall, 2014).

Many studies have investigated the notion that LM practices provide an approach to improving the OP of organizations, not only in manufacturing sectors but also in the service sectors. Several studies have succeeded in providing evidence that LM has a positive impact on performance (MoyanoFuentes and Sacristán-Díaz, 2012). Accordingly, LM has exploded in popularity due to the demonstrated improvement in financial, operational and organizational performance enjoyed by so many organizations that have implemented a LM philosophy. Among the benefits most often mentioned of LM are stock reduction, quality improvement, greater productivity, develop efficient processes in terms of reduction on variation, reduction on cost, shorter lead time, on-time delivery and reduction on batch sizes, (Womack, Jones and Roos, 1990; Shah and Ward, 2003; Bonavia and MarinGarcia, 2011) and respond to competitive pressures from other organizations and legislation (Radnor, 
Holweg and Waring, 2012). Within public services, the main drivers also include less tangible elements such as a change of leadership, struggle with performance indicators, government agendas, changes in policy, making better use of staff time, reduction in errors, the threat of open competition, and service expansion with limited or reduced resources (Radnor, Holweg and Waring, 2012).

The attempts of scholars to establish the relevance of HRM to LM in the extant literature is evident (Shah and Ward, 2003; Liker, 2004; Shah and Ward, 2007; Michie, Sparrow, Cooper and Hird, 2016). For instance, Liker (2004) allocates three principles of LM to HRM: Principles 9: Grow leaders who thoroughly understand the work, live the philosophy, and teach it to others, Principle 10: Develop exceptional people and teams who follow your company's philosophy, and Principle 11: Respect your extended network of partners and suppliers by challenging them and helping them improve. These three principles do set the general guidelines with regard of the importance of developing people and managing their behavior. Furthermore, as Michie, Sparrow, Cooper and Hird (2016) note, the application of LM into service sector has further increased the relevance of HRM in a LM context. They find that LM is an opportunity for HRM to review its internal architecture and design to prove more useful in a LM system. Thus, HRM is relevant to LM for mainly three reasons: it aims to bring LM an integration of business strategy with quality, a committed workforce and increased flexibility in terms of organization and job design (Wilkinson, Gamble, Humphrey, Morris and Anthony, 2001), and positive employee attitudes (Zirar, Radnor and Charlwood, 2015).

The relationship between HRM practices, LM and OP has been well documented by the previous studies. Some studies have noted that LM promotes OP (Shah and Ward, 2003; Larsson and Westerberg, 2009; Crawford, 2012; Drotz, 2014; Birkie, 2015; Fok-Yew, 2016), other studies argue that it is HRM that helps to improve this performance (Huselid, 1995; Becker and Gerhart, 1996; ALDamoe, Yazam and Ahmid, 2012). While, some research suggests that LM and HRM are closely related and can interact in order to improve OP (Bonavia and Marin-Garcia, 2011; Marshall, 2014; Szabo, 2014; Zirar, Radnor and Charlwood, 2015; Uhrin, Bruque-Cámara and Moyano-Fuentes, 2017). Sakakibara Flynn, Schroeder and Morris (1997) show a strong relationship between JIT and what they called infrastructure practices, including workforce management. Cua, McKone and Schroeder (2001) also show how LM programs include some HRM practices. Their analysis make clear how the implementation of these human practices, together with TQM, JIT, and TPM programs, provides significant explanation for the differences in performance measures (Bonavia and MarinGarcia, 2011).

However, the study observes that, despite HRM practices involving significant changes in LM implementation, there is no consensus in the literature on the way that LM might affect people (Conti, Angelis, Cooper, Faragher and Gill, 2006; De Treville and Antonakis, 2006), or the role of HRM practices during the LM implementation process (Liker and Hoseus, 2009, Bonavía and Marín-García, 2011, Martínez-Jurado, Moyano-Fuentes and Jerez-Gómez, 2014). Womack, Jones and Roos (1990) do not explain how HRM practices are integrated into these different production systems, nor do they test the relationship between HRM practices and performance. MacDuffie (1995) echoes this criticism and declares that much of the research on the performance of automotive assembly plants has overemphasized either the technical system or the HRM system without fully exploring the interaction of the two systems and how it can affect performance. Paez, Dewees, Genaidy, Tuncel, Karwowski and Zurada (2004) point out LM represents a change in the production system model that calls for integration of human and technological practices.

There is a quantitative study of LM implementation in manufacturing has found evidence that despite a positive role of HRM on the operations of an organization in a LM context, its role is indirect and mediated through two main bundles of LM: Just-In-Time (JIT) and Total Quality Management (TQM) (Dal Pont, Furlan, and Vinelli, 2008). However, this type of research can only identify statistical associations between HRM and LM, it cannot identify the nature of the relationship between them. Do HRM systems have a causal influence on LM, with HRM practices like recruitment and selection, training and performance management systems contributing to workers having the skills and orientations to make LM work (a proposition that makes theoretical sense).

As an outcome of the previous studies on LM and HRM practices in relationship with OP, it can be seen that their relationship lacks transparency about what exactly leads to what. Theoretically, LM and HRM practices have a positive effect on OP, even they both could interact in order to improve OP. Based on this arguments, it is suggested in this study that HRM practices will mediate the relationship between LM and OP of Malaysia public sector.

\section{Methodology}


Data from 447 respondents of Malaysia LAs have been collected using structured survey questionnaire. The survey questionnaire is in four parts: the first part is on LM, the second part is on HRM practices, the third part is on OP, and the final part is on respondent and organization background information. The questions are designed as a closed-end questions, where the respondents have to make their response in a seven point Likert scale, varying from "Strongly Disagree" to "'Strongly Agree". The respondent are senior level managements of 149 Malaysia LAs (including Kuala Lumpur City Hall), consisting of 14 City Councils, 37 Municipal Councils and 98 District Councils. In this respect, we invite three senior level managements from each LAs from department of management service, administration and human resources and department of corporate, community development and quality to participate in the survey.

\section{Data Analysis}

The current research utilizes Partial Least Square-Structural Equation Modeling (PLS-SEM) approach for data analysis. PLS-SEM as a multivariate analysis method has increased in popularity among recent operations management studies (Peng and Lai, 2012; Ching, 2016), and has been utilized for years by many other disciplines (Rai, Patnayakuni and Seth, 2006; Benitez-Amado, Llorens-Montes and Nieves Perez-Arostegui, 2010; Benitez-Amado and Walczuch, 2012, Ching, 2016). In fact, Goodhue, Lewis and Thompson (2006) found that research published in well-respected journals from other business disciplines from 2000-2003 relied on PLS-SEM as the chosen method for data analysis in approximately one third of the studies (Marshall, 2014). Hair, Sarstedt, Pieper and Ringle (2012) also revealed that the cumulative number of studies between 1985 and 2010 using PLSSEM in strategic management field has significantly increased. According to Hair, Ringle and Sarstedt (2013), bootstrap re-sampling method with 5000 subsamples was employed all throughout these researches.

Following these leads, this research utilizes PLS-SEM approach for data analysis because PLSSEM is able to handle problematic modeling issues that routinely occur in the social sciences. PLSSEM has a few distinct features that distinguish the method from covariance-based SEM (CB-SEM) which are best suits the study research objective, data characteristics, and model set-up such as: (1) causal-predictive analysis, (2) multivariate normal distribution assumption, (3) small sample sizes, (4) combination of reflective and formative constructs, and (5) complex model (Hair, Ringle and Sarstedt, 2011; Hair, Sarstedt, Ringle and Mena 2012; Hair, Ringle and Sarstedt, 2013).

\section{Conclusions}

This study investigates from RBV theory perspective, the role of LM in improving OP with the mediating effects of HRM practices in Malaysia LAs. It examines LM from the perspective of RBV which explores the human resources as a key resources that are imperfectly imitable and difficult to duplicate. These key resources are formed by HRM practices of the organization. A survey research method has been adopted to collect the data from 149 Malaysia LAs, where the instruments have been adopted from the previous well-established author and researchers. The data is analyzed through PLSSEM technique. The study empirically demonstrates that achieving high level of OP results from LM practices which in turn is driven by HRM practices.

This study represents the first comprehensive examination of the role that HRM practices play in the overall success of LM implementation in improving OP in Malaysia LAs. This study could build momentum by stimulating new research in public sector that will not only close the gaps, but will also lead practice. Hence, it becomes the major contribution to the body of knowledge in the LM public sector operations management literature. This study is anticipated to be a framework for future studies in the academic field and public sector LM implementers.

\section{References}

ALDamoe, F.M.A., Yazam, M. and Ahmid, K.B. (2012). The Mediating Effect of HRM Outcomes (Employee Retention) on the Relationship between HRM Practices and Organizational Performance. International Journal of Human Resource Studies, 2(1): 75.

Azmi, I. A. G. (2008). Amalan Pengurusan Sumber Manusia Berteraskan Kompetensi dan Kualiti Perkhidmatan Dalam Organisasi Awam di Malaysia: Kesaling Bergantungan Tugasan Sebagai Penyederhana (Doctoral Dissertation, Universiti Sains Malaysia).

Barney, J. (1991). Firm Resources and Sustained Competitive Advantage. Journal of Management, 17(1): 99-120. 
Batt, R. (2002). Managing Customer Services: Human Resource Practices, Quit Rates, and Sales Growth. Academy of Management Journal, 45(3): 587-597.

Becker, B. and Gerhart, B. (1996). The Impact of Human Resource Management on Organizational Performance: Progress and Prospects. Academy of Management Journal, 39(4): 779-801.

Benitez-Amado, J., \& Walczuch, R. M. (2012). Information Technology, the Organizational Capability of Proactive Corporate Environmental Strategy and Firm Performance: A Resource-Based Analysis. European Journal of Information Systems, 21(6): 664-679.

Benitez-Amado, J., Llorens-Montes, F. J., \& Nieves Perez-Arostegui, M. (2010). Information Technology-Enabled Intrapreneurship Culture and Firm Performance. Industrial Management \& Data Systems, 110(4): 550-566.

Birkie, S.E. (2015). Be Lean to be Resilient: Setting Capabilities for Turbulent Times.

Bonavia, T. and Marin-Garcia, J.A. (2011). Integrating Human Resource Management into Lean Production and Their Impact on Organizational Performance. International Journal of Manpower, 32(8): 923-938.

Boselie, P., Dietz, G. and Boon, C. (2005). Commonalities and Contradictions in HRM and Performance Research. Human Resource Management Journal, 15(3): 67-94.

Bourne, M., Mills, J., \& Faull, N. (2003). Operations Strategy and Performance: A ResourceBased Perspective. International Journal of Operations \& Production Management, 23(9): 944-946.

Ching, N. (2016). Determining Lean Manufacturing Effectiveness in Malaysia Using Hybrid Interpretive Structural and Structural Equation Models.

Conti, R., Angelis, J., Cooper, C., Faragher, B. and Gill, C. (2006). The Effects of Lean Production on Worker Job Stress. International Journal of Operations \& Production Management, 26(9): 1013-1038.

Crawford, J. (2012). Lean Production in the Public Service Sector.

Cua, K.O., McKone, K.E. and Schroeder, R.G. (2001). Relationships between Implementation of TQM, JIT, and TPM and Manufacturing Performance. Journal of Operations Management, 19(6): 675-694.

Curristine, T., Lonti, Z. and Joumard, I. (2007). Improving Public Sector Efficiency: Challenges and Opportunities. OECD Journal on Budgeting, 7(1): $1 D$.

Dal Pont, G., Furlan, A. and Vinelli, A. (2008). Interrelationships among Lean Bundles and Their Effects on Operational Performance. Operations Management Research, 1(2): 50-158.

De Treville, S. and Antonakis, J. (2006). Could Lean Production Job Design be Intrinsically Motivating? Contextual, Configurational, and Levels-of-Analysis Issues. Journal of Operations Management, 24(2): 99-123.

Denhardt, R.B. and Denhardt, J.V. (2000). The New Public Service: Serving Rather Than Steering. Public Administration Review, 60(6): 549-559.

Dombrowski, U. and Mielke, T. (2013). Lean Leadership-Fundamental Principles and Their Application. Procedia CIRP, 7, pp.569-574.

Drotz, E. (2014). Lean in the Public Sector: Possibilities and Limitations (Doctoral Dissertation, Linköping University Electronic Press).

Fok-Yew, O. (2016). The Mediating Role of Lean Engagement on Lean Practices and Business Excellence in Malaysia Electrical and Electronics Companies. International Journal of Academic Research in Economics and Management Sciences. 5(2): 35-45.

Goodhue, D., Lewis, W. and Thompson, R. (2006), January. PLS, Small Sample Size, and Statistical Power in MIS Research. In System Sciences, 2006. HICSS'06. Proceedings of the 39th Annual Hawaii International Conference on (Vol. 8, pp. 202b-202b). IEEE. 
Hair, J. F., Ringle, C. M., \& Sarstedt, M. (2011). PLS-SEM: Indeed a silver bullet. Journal of Marketing Theory and Practice, 19(2): 139-152.

Hair, J. F., Ringle, C. M., \& Sarstedt, M. (2013). Editorial-Partial Least Squares Structural Equation Modeling: Rigorous Applications, Better Results and Higher Acceptance, 2013. Social Science Research Network, Rochester, NY.

Hair, J. F., Sarstedt, M., Pieper, T. M., \& Ringle, C. M. (2012). The Use of Partial Least Squares Structural Equation Modeling in Strategic Management Research: A Review of Past Practices and Recommendations for Future Applications. Long Range Planning, 45(5-6): 320-340.

Hair, J. F., Sarstedt, M., Ringle, C. M., \& Mena, J. A. (2012). An Assessment of the Use of Partial Least Squares Structural Equation Modeling in Marketing Research. Journal of the Academy of Marketing science, 40(3): 414-433.

Hamid, S.M.B.A., Hamali, J.B.H. and Abdullah, F. (2016). Performance Measurement for Local Authorities in Sarawak. Procedia-Social and Behavioral Sciences, 224, pp.437-444.

Hookana, H. (2010). Measurement of effectiveness, Efficiency and Quality in Public Sector Services: Interventionist Empirical Investigations. In MIC 2011: Managing Sustainability? Proceedings of the 12th International Conference, Portorož, 23-26 November 2011 [Selected Papers] (pp. 491-510). University of Primorska, Faculty of Management Koper.

Huselid, M.A. (1995). The Impact of Human Resource Management Practices on Turnover, Productivity, and Corporate Financial Performance. Academy of Management Journal, 38(3): 635-672.

Johnston, R. and Jones, P. (2004). Service Productivity: Towards Understanding the Relationship Between Operational and Customer Productivity. International Journal of Productivity and Performance Management, 53(3): 201-213.

Larsson, R. and Westerberg, E. (2009). Applying Lean in Haulers' Operations. Chalmers University of Technology.

Latham, G.P., Almost, J., Mann, S. and Moore, C. (2005). New Developments in Performance Management. Organizational Dynamics, 34(1): 77-87.

Liker, J. (2004). The Toyota way: 14 Management Principles from the World's Greatest Manufacturer. New York: McGraw-Hill.

Liker, J.K. and Hoseus, M. (2009). Human Resource Development in Toyota culture. International Journal of Human Resources Development and Management, 10(1): 34-50.

MacDuffie, J.P. (1995). Human Resource Bundles and Manufacturing Performance: Organizational Logic and Flexible Production Systems in the World Auto Industry. ILR Review, 48(2): 197-221.

Marshall, D.A. (2014). Lean Transformation: Overcoming the Challenges, Managing Performance, and Sustaining Success.

Martínez-Jurado, P.J., Moyano-Fuentes, J. and Jerez-Gómez, P. (2014). Human Resource Management in Lean Production Adoption and Implementation Processes: Success Factors in the Aeronautics Industry. BRQ Business Research Quarterly, 17(1): 47-68.

Michie, J., Sparrow, P., Cooper, C. and Hird, M. (2016). Do we Need HR?: Repositioning People Management for SuccesS. Springer.

Mouzas, S. (2006). Efficiency versus effectiveness in Business Networks. Journal of Business Research, 59(10): 1124-1132.

Moyano-Fuentes, J. and Sacristán-Díaz, M. (2012). Learning on Lean: A Review of Thinking and Research. International Journal of Operations \& Production Management, 32(5): 551-582.

Narasimhan, R., Swink, M. and Kim, S.W. (2006). Disentangling Leanness and Agility: an Empirical Investigation. Journal of Operations Management, 24(5): 440-457. 
Paez, O., Dewees, J., Genaidy, A., Tuncel, S., Karwowski, W. and Zurada, J. (2004). The Lean Manufacturing Enterprise: An Emerging Sociotechnological System Integration. Human Factors and Ergonomics in Manufacturing \& Service Industries, 14(3): 285-306.

PCB (Public Complaints Bureau). (2017). Statistical Complaints (online). On the WWW, April. URL http://www.pcb.gov.my.

Peng, D. X., \& Lai, F. (2012). Using Partial Least Squares in Operations Management Research: A Practical Guideline and Summary of Past Research. Journal of Operations Management, 30(6): 467-480.

Puvanasvaran, A.P. (2011). People Development System as A Pillar in Implementing Lean for Public Sector.

Radnor, Z. (2012). Why Lean Matters: Understanding and Implementing Lean in Public Services. New York: Advanced Institute of Management Research (AIM).

Radnor, Z. and Osborne, S.P. (2013). Lean: A Failed Theory for Public Services?. Public Management Review, 15(2): 265-287.

Radnor, Z.J., Holweg, M. and Waring, J. (2012). Lean in Healthcare: The Unfilled Promise?. Social Science \& Medicine, 74(3): 364-371.

Rai, A., Patnayakuni, R., \& Seth, N. (2006). Firm Performance Impacts of Digitally Enabled Supply Chain Integration Capabilities. MIS quarterly, 225-246.

Sagwa, E.V., K'Obonyo, P. and Ogutu, M. (2015). Mediation Effect of Employee Outcomes in the Relationship between Human Resource Management Practices and Performance of Firms Listed on the Nairobi Securities Exchange.

Sakakibara, S., Flynn, B.B., Schroeder, R.G. and Morris, W.T. (1997). The Impact of Just-In-Time Manufacturing and Its Infrastructure on Manufacturing Performance. Management Science, 43(9): 1246-1257.

Shah, R. and Ward, P.T. (2003). Lean Manufacturing: Context, Practice Bundles, and Performance. Journal of Operations Management, 21(2): 129-149.

Shah, R. and Ward, P.T. (2007). Defining and Developing Measures of Lean Production. Journal of Operations Management, 25(4): 785-805.

Szabo, T.D. (2014). Strategic Human Resource Management and Lean Transformation in Sunrise Health Region. Master Thesis. Athabasca University, Canada.

Talib, D. (2010). Pengukuran Prestasi Pihak Berkuasa Tempatan (PBT) Malaysia Berasaskan Pengaruh Faktor-Faktor Dalaman Organisasi. Malaysia Productivity Corporation, Malaysia.

Uhrin, Á., Bruque-Cámara, S. and Moyano-Fuentes, J. (2017). Lean Production, Workforce Development and Operational Performance. Management Decision, 55(1).

Ulrich, D. (2013). Human Resource Champions: The Next Agenda for Adding Value and Delivering Results. Harvard Business Press.

Wilkinson, B., Gamble, J., Humphrey, J., Morris, J. and Anthony, D. (2001). The New International Division of Labour in Asian Electronics: Work Organization and Human Resources in Japan and Malaysia. Journal of Management Studies, 38: 675-695.

Womack, J.P., Jones, D.T. and Roos, D. (1990). Machine that Changed the World. Simon and Schuster.

Yusoff, M. (2008). Strategic Management in the Public Sector: An Interpretive Study of the Application of Strategic Management Practices in the Local Authorities in Malaysia (Doctoral Dissertation, University of Hull).

Zakaria, M.N., Al Mamun, A., Nawi, N.B.C. and Razak, R.C. (2016). Service Operations Practice and Performance of Local Authorities in Malaysia. The Journal of Developing Areas, 50(5), pp. 423-430. 
The Turkish Online Journal of Design, Art and Communication - TOJDAC

ISSN: 2146-5193, September 2018 Special Edition, p.1167-1175

Zakaria, Z. (2011). Measuring LAs Performance in Malaysia: Political Indicators versus Organizational Theory. Voice of Academia. 6(1).

Zirar, A.A., j, Z.J. and Charlwood, A. (2015). The Relevance of the Human Resource Management (HRM) to Lean in the Service Sector: Evidence from Three Exploratory Case Studies. 